\title{
UJI MORTALITAS KECOA AMERIKA (Periplaneta americana) MENGGUNAKAN EKSTRAK KULIT DURIAN (Durio zibethinus M urr)
}

\author{
Denai W ahyuni*, Risa Etika M uktitama ** \\ * Prodi Kesehatan M asyarakat STIKes Hang Tuah Pekanbaru \\ **Prodi Teknologi Laboratorium M edis A kademi A nalis Kesehatan Yayasan Fajar Pekanbaru. \\ denaiwahyui69@gmail.com
}

\begin{abstract}
ABSTRAK
Kecoa dapat menularkan penyakit kepada manusia baik secara mekanis maupun secara biologis antara lain disentri, diare, cholera, virus hepatitis A dan polio pada anak-anak.Salah satu upaya yang dapat dilakukan dalam mengurang kecoa amerika tanpa menggunakan insektisida sintetik adalah dengan menggunakan ekstrak kulit durian (Durio zibethinus Murr). Tujuandaripenelitianiniuntukmenentukankandungansenyawametabolitsekunder yang terdapat dalam kulit durian, menentukan mortalitas kecoa amerika dan menentukan nilai LC 50 . Penelitian ini dilakukan dengan menggunakan metode experimental laboratory secara in vivo. Ekstrak kulit durian dibuat dalam berbagai konsentrasi yaitu5\%, 10\%, 20\%, dan 30\%, kemudian masukkan kecoa amerika kedalam kotak uji dan diamati selama 3 jam. Berdasarkan hasi Ipenelitian, ekstrak kulit durian mengandung senyawa flavonoid, saponin, tanin dan alkaloid. Persentase dar imortalitas kecoa amerika. pada konsentrasi 5\%, 10\%, 20\% dan 30\% berturut-turut yaitu11,11\%,22,22\%, 38,88\% dan 61,11\% dengan nilai LC $502,63 \times 10^{5} \mathrm{ppm}$. Dapat disimpulkan bahwa ekstrak kulit durian mampu membunuh kecoa amerika yang ditandai dengan adanya persentase kematian kecoa amerika.

Kata kunci: Uji mortalitas, kulit durian, kecoa amerika
\end{abstract}

\section{ABSTRACT}

Cockroaches can transmit disease to humans both mechanically and biologically, among others, dysentery, diarrhea, cholera, hepatitis $A$ virus and polio in children. One effort that can be done in reducing the American cockroach without using synthetic insecticides is by using durian leaf extract (DuriozibethinusM urr). The purpose of this study was to determine the content of secondary metabolite compounds present in the skin of durian, determining the mortality of the American cockroaches and determining the LC50 value. This research was conducted by using experimental laboratory method in vivo. Durian leather extracts were made in various concentrations of $5 \%, 10 \%, 20 \%$, and $30 \%$, then put the American cockroach into the test box and observed for 3 hours. Based on the research, durian leaf extract contains flavonoid compounds, saponins, tannins and alkaloids. Percentage of mortality of American cockroaches. at concentrations of 5\%, 10\%, 20\% and $30 \%$ respectively ie $11.11 \%, 22.22 \%, 38.88 \%$ and $61.11 \%$ with LC50 values of $2,63 \times 10^{5} \mathrm{ppm}$. It can be concluded that durian skin extract is capable of killing A merican cockroaches characterized by the percentage of death of American cockroaches. Keywords: mortality test, A merican cockroach 


\section{PENDAHULUAN}

Salah satu usaha sanitasi lingkungan adalah dengan pengendalian vektor penyakit. Kriteria lingkungan sehat adalah lingkungan yang terbebas dari unsur-unsur yang dapat menimbulkan penyakit yakni: limbah (cair, padat dan gas), radiasi, kebisingan, zat berbahaya, sampah yang tidak diproses dan vektor penyakit (Triwibowo \& Pusphandani, 2013).

Kecoa merupakan salah satu vektor, yang termasuk dalam Phylum Arthropoda dan Kelas Insecta yang mempunyai bentuk tubuh oval dan pipih. Kecoa berperan sebagai vektor penyakit dan dekat kehidupannya dengan manusia (Sucipto, 2011). Kecoa amerika (Periplaneta americana) biasa didominasi di daerah tropik walau ada sebagian yang hidup di daerah dingin. Kecoa ini banyak ditemukan pada daerah sampah, vegetasi, rumah maupun tanah dan sebagian hidup di daerah gua. Tempat perindukan kecoa lebih menyukai tempattempat yang kotor, lembab dan sejuk, seperti WC, di bawah tumpukan barang-barang, di gudang yang lembab dan berbau atau di tempat-tempat yang gelap lainnya. Cara hidup kecoa umumnya tinggal berkelompok dan mempunyai peranan yang cukup penting dalam penularan penyakit. Peranan tersebut antara lain sebagai vektor mekanik bagi beberapa mikro organisme patogen, sebagai inang perantara spesies cacing, menyebabkan timbulnya reaksi-reaksi alergi seperti dermatitis, gatal-gatal dan pembengkakan kelopak mata, dan kecoa dapat memindahkan beberapa mikro organisme patogen antara lain, Streptococcus, Salmonella dan lain-lain sehingga mereka berperan dalam penyebaran penyakit antara lain, disentri, diare, cholera, virus hepatitis $A$, dan polio pada anak-anak (Wahyuni dkk, 2017). (Sucipto, 2011) menjelaskan bahwa, Kecoa A merika salah satu jenis yang berbahaya, karena memiliki perilaku memakan makanan dan kotoran lalu memuntahkan kembali sebagian makanan yang telah dicernanya dan menyukai tempat seperti saluran pembuangan air limbah, septic tank, selokan dan tempat sampah.

Pengendalian kecoa yang biasa dilakukan dengan 3 metode yaitu; pengendalian secara fisik dan mekanik, pengendalian secara biologi serta pengendalian secara kimia. Pemakaian insektisida sintetik dapat menimbulkan dampak negatif terhadap manusia, lingkungan dan organisme lain. Bagi manusia sebagai pengguna dapat menimbulkan keracunan akut, bagi lingkungan dapat mencemari air, udara dan tanah. Sementara bagi organisme lain dapat membunuh musuh alami dari hama dan resistensi hama pada pestisida. Maka dari itu perlu dilakukan alternatif lain penggunaan insektisida sintetik. Salah satu cara yang dapat dilakukan yaitu dengan menggunakan insektisida nabati yang berasal dari ekstrak tumbuhan.

Salah satu tanaman yang berpotensi sebagai insektisida nabati adalah Kulit Durian (Durio zibethinus Murr). Ekstrak kulit durian mengandung senyawa flavonoid, saponin, tanin, alkaloid, unsur selulosa, lignin, serta kandungan pati dan minyak atsiri Saponin merupakan senyawa aktif yang dapat menimbulkan busa, dapat menyebabkan hemolisissel darah merah, mempunyai rasa pahit dan menurunkan tegangan permukaan sehingga merusak membran sel dan dapat menggangu metabolisme serangga. Flavonoid merupakan inhibitor pernafasaan dengan mekanisme yang dapat melemahkan saraf (Prabowo, 2012). 
Penelitian sebelumnya yang telah dilakukan oleh (M ardiyah \& Royaldi, 2005) menyatakan bahwa ekstrak kulit durian dapat mengusir nyamuk Aedes aegypti dengan konsentrasi $25 \%$. Pada penelitian (Astuti \& Soekardi, 2014) menyatakan bahwa ekstrak daun sirsak (Anona muricata $L$ ) dapat membunuh kecoa amerika dengan konsentrasi $5 \%$. Pemilihan kulit durian sebagai objek penelitian dikarenakan kulit buah biasanya hanya dibuang dan menjadi sampah, padahal juga berpotensi mengandung senyawa aktif anti serangga. Namun penelitian tentang ekstrak kulit durian terhadap kematian kecoa amerika belum pernah dilakukan, maka penulis tertarik untuk melakukan penelitian tentang uji mortalitas kecoa amerika setelah pemberian ekstrak kulit durian. Penelitian ini bertujuan melihat kandungan senyawa metabolit sekunder yang terdapat dalam kulit durian, menentukan mortalitas kecoa amerika dan nilai $L C_{50}$.

\section{METODE}

Lokasi dan Waktu Penelitian

Penelitian ini dilakukan di Laboratorium Mikrobiologi \& Parasitologi AAK Yayasan Fajar Univ. Abdurrab Pekanbaru dan Laboratorium Kimia Organik Fakultas Matematika dan IImu Pengetahuan Alam (FMIPA) Universitas Riau Pekanbaru pada bulan Januari-Februari 2018.

\section{Serangga Uji}

Populasi dalam penelitian ini adalah seluruh kecoa yang dikumpulkan dengan cara penangkapan secara manual dengan menggunakan perangkap sederhana dan mendapatkan dari pedagang burung yang menjual kecoa. H ewan uji yang digunakan benar-benar sehat dengan ciri-ciri tidak cacat fisik (bagian tubuh masih lengkap) dan aktif bergerak (A malia \& H arahap, 2010). Sampel pengujian untuk masing-masing konsentrasi terdiri dari 6 ekor kecoa, dengan total sampel keseluruhan berjumlah 108 ekor.

\section{Tanaman Sumber dan Pembuatan Ekstrak Kulit Durian}

Sampel kulit durian diperoleh dari pedagang durian yang berada di daerah Simpang Arifin Ahmad Kota Pekanbaru. Diambil kulit durian yang masih segar sebanyak 2000 gr. Kulit durian tersebut selanjutnya dicuci dengan air yang mengalir, lalu dipisahkan bagian kulit durian yang berduri dari bagian kulit putih. Kulit durian yang telah bersih tersebut selanjutnya dipotong kecil-kecil lalu dikering anginkan yang terhindar dari sinar matahari langsung lebih kurang selama satu minggu. Kulit durian yang telah kering ditimbang dengan berat kering sebanyak 800 gram, selanjutnya direndam dengan etanol $96 \%$ dimaserasi selama 3 - 4 hari sambil sesekali diaduk. Pelarut diuapkan dengan menggunakan Rotary Vacum Evaporator hingga didapatkan ekstrak kental (Ningsih dkk, 2015). Ekstrak yang sudah didapatkan disimpan dalam lemari pendingin sampai saat akan digunakan. 


\section{M etoda Pengujian}

Penelitian ini menggunakan ekstrak kulit durian dengan 4 konsentrasi5\%, 10\%, 20\% dan 30\% dan $\mathrm{K}(+)$ menggunakan baygon semprot yang mengandung sipermetrin, $\mathrm{K}(-)$ menggunakan aquades dengan 3 kali pengulangan. Untuk mendapatkan konsentrasi 5\%:0,25 gram ekstrak kulit durian ditambahkan akuades sebanyak 4,75 $\mathrm{ml}$ dan dimasukkan ke dalam botol sprayer dan selanjutnya dilakukan hal yang sama untuk konsentrasi yang lainnya.

\section{Pelaksanaan Pengujian}

Hasil ekstrak kulit durian selanjutnya dimasukkan ke dalam botol spayer dengan empat macam konsentrasi yaitu5\%, 10\%. 20\%, dan 30\%, untuk kontrol negatif menggunakan akuades, kontrol positif menggunakan baygon semprot (sipermetrin). Disiapkan kotak percobaan lalu masukkan 6 ekor kecoa amerika dewasa pada tiap kotak, lalu disemprotkan masing-masing konsentrasi tersebut. Selanjutnya dilakukan pengamatan setelah 3 jam penyemprotan lalu dihitung jumlah kecoa yang mati pada masing-masing kotak percobaan. Pada akhir setiap perlakuan, kecoa yang tidak mati pada akhir pengamatan didiamkan sampai mati sendiri atau dibunuh dengan menggunakan baygon semprot. $\mathrm{Hal}$ ini dilakukan pada masing-masing pengulangan kedua dan ketiga. Pengamatan perilaku kecoa dengan melihat kondisi perubahan tingkah laku, gerak dan kondisi fisik yang terjadi setel ah pemberian ekstrak kulit durian.

\section{Identifikasi Senyawa Fitokimia}

Hasil ekstraksi kulit durian dari pelarut etanol dilakukan uji secara kualitatif untuk mengetahui kandungan senyawa metabolit sekunder yang ada di dalam ekstrak kulit durian tersebut. Identifikasi senyawa fitokimia yang dilakukan adalah uji saponin, flavonoid, tanin dan alkaloid.

\section{Analisa Data}

Data yang diperoleh dari hasil percobaan disajikan dalam bentuk tabel, dilanjutkan dengan Analisis Probit untuk melihat efektifitas insektisida ekstrak durian terhadap mortalitas kecoa amerika berdasarkan $\mathrm{LC}_{50}$.

\section{HASIL DAN PEMBAHASAN}

\section{A. Hasil Penelitian}

Efek paparan ekstrak kulit durian terhadap kecoa pada berbagai konsentrasi perlakuan, kecoa tampak gelisah melakukan gerakan turun naik, tubuh melemah dan tidak dapat menggerakan badan sehingga mati. Warna tubuh kecoa berubah menjadi kehitaman akibat ekstrak yang telah disemprotkan 


\section{Identifikasi Senyawa Fitokimia}

Hasil Ekstraksi kulit durian dari pelarut etanol dilakukan uji secara kualitatif untuk mengetahui kandungan senyawa metabolit sekunder yang ada di dalam ekstrak kulit durian tersebut. Hasil identifikasi kandungan senyawa fitokimia dari ekstrak kulit durian dapat dilihat pada Tabel 1

Tabel $1 \mathrm{H}$ asil Identifikasi Senyawa Fitokimia Ekstrak Kulit D urian

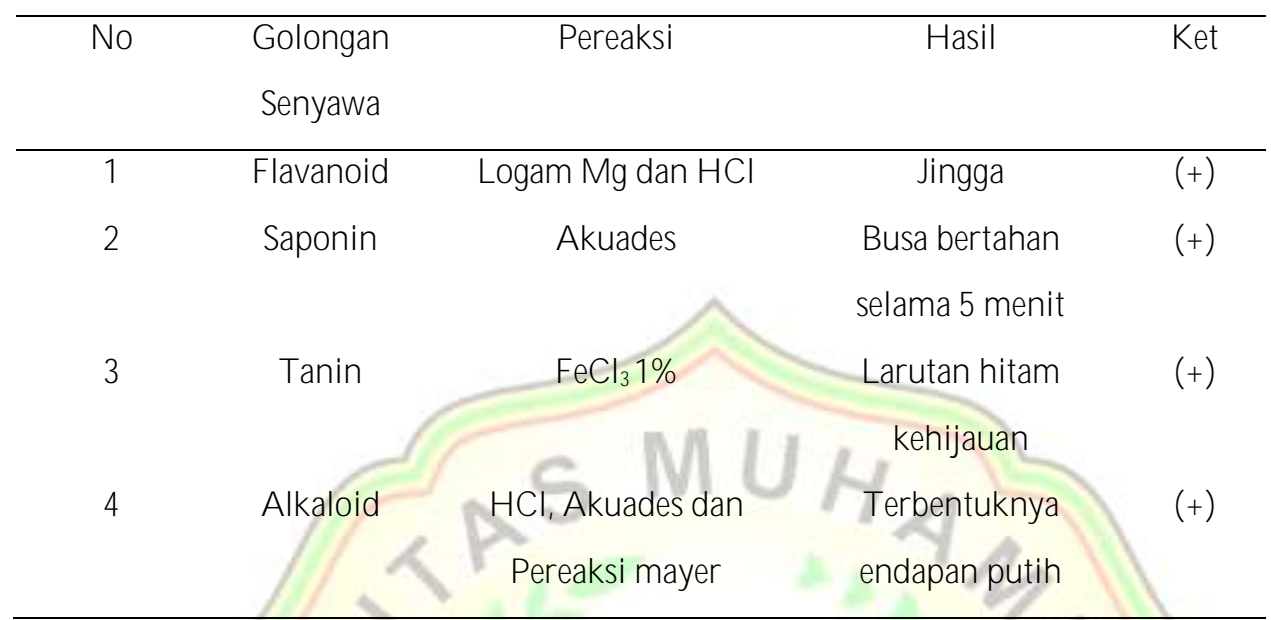

Keterangan (+) : memiliki kandungan senyawa

Keterangan (-) : tidak memiliki kandungan senyawa

Hasil dari identifikasi kandungan senyawa fitokimia ekstrak kulit durian didapatkan adanya senyawa saponin, flavonoid, tanin, dan alkaloid.

Uji M ortalitas Kecoa A merika M enggunakan Ekstrak Kulit Durian

Pengujian mortalitas kecoa amerika ini menggunakan ekstrak kulit durian yang telah terbukti memiliki kandungan senyawa metabolit yang diinginkan melalui identifikasi senyawa fitokimia. Hasil mortalitas kecoa amerika setelah diberikan ekstrak kulit durian selama 3 jam dapat dilihat pada Tabel 2 di bawah ini.

Tabel $2 \mathrm{H}$ asil M ortalitas Kecoa Amerika Setelah Pemberian Ekstrak Etanol Kulit Durian Selama $3 \mathrm{Jam}$

\begin{tabular}{|c|c|c|c|c|c|c|}
\hline \multirow{4}{*}{ No } & \multirow{4}{*}{$\begin{array}{c}\text { Konsentrasi } \\
\text { Ekstrak }\end{array}$} & \multicolumn{5}{|c|}{ Jumlah Kecoa amerika dewasa yang mati } \\
\hline & & \multicolumn{3}{|c|}{ Pengulangan $A$} & \multirow{3}{*}{ Rata-rata } & \multirow{3}{*}{$\begin{array}{l}\text { Persentase } \\
\text { Kematian } \\
\text { Kecoa (\%) }\end{array}$} \\
\hline & & & & & & \\
\hline & & 1 & 2 & 3 & & \\
\hline 1 & $5 \%$ & 1 & 0 & 1 & 0,66 & 11,11 \\
\hline 2 & $10 \%$ & 2 & 1 & 1 & 1,33 & 22,22 \\
\hline 3 & $20 \%$ & 2 & 2 & 2 & 2 & 33,33 \\
\hline 4 & $30 \%$ & 4 & 4 & 3 & 3,66 & 61,11 \\
\hline 6 & Kontrol $(+)$ & 6 & 6 & 6 & 6 & 100,00 \\
\hline 7 & Kontrol (-) & 0 & 0 & 0 & 0 & 0 \\
\hline
\end{tabular}


Berdasarkan Tabel 2 di atas dapat dilihat bahwa setelah pemberian ekstrak kulit durian yang diamati selama 3 jam menunjukkan masing-masing konsentrasi dari ekstrak kulit durian dapat membunuh kecoa amerika. Hasil uji yang telah dilakukan, terhadap kecoa amerika dengan menggunakan ekstrak etanol kulit durian pada konsentrasi $5 \%$, 10\%, 20\%, dan 30\% adalah $11,11 \%$, 22,22\%, 33,33\%, dan $61,11 \%$. Kematian kecoa amerika terendah pada konsentrasi $5 \%$ yang mencapai $11,11 \%$ dan kematian tertinggi pada konsentrasi $30 \%$ yaitu $61,11 \%$. Pada kontrol positif menunjukan adanya kematian kecoa yang mencapai $100 \%$ dan pada kontrol negatif menunjukkan tidak terjadi kematian pada kecoa. Konsentrasi ekstrak kulit durian yang telah digunakan menunjukkan adanya kandungan toksik yang dapat membunuh kecoa amerika dewasa. Besarnya kandungan toksik tersebut dapat diketahui dengan mencari nilai $\mathrm{LC}_{50}$ (Lethal concentration 50 ) melalui rumus linear yang diperoleh dari grafik nilai probit mortalitas kecoa amerika terhadap kulit durian. Data grafik nilai probit dapat dilihat pada Tabel 3 dan grafik nilai probit mortalitas kecoa amerika terhadap ekstrak kulit durian, dapat dilihat pada Gambar 1.

Tabel 3 Data Grafik Nilai Probit M ortalitas Ekstrak Kulit D urian Terhadap Kecoa Amerika.

\begin{tabular}{cccc}
\hline $\begin{array}{c}\text { Konsentrasi } \\
\text { ekstrak (\%) }\end{array}$ & Konsentrasi (ppm) & Log Konsentrasi & Nilai Probit \\
\hline $5 \%$ & 50.000 & 4,698 & 3,77 \\
$10 \%$ & 100.000 & 5 & 4,23 \\
$20 \%$ & 200.000 & 5,301 & 4,56 \\
$30 \%$ & 300.000 & 5,477 & 5,28 \\
\hline
\end{tabular}

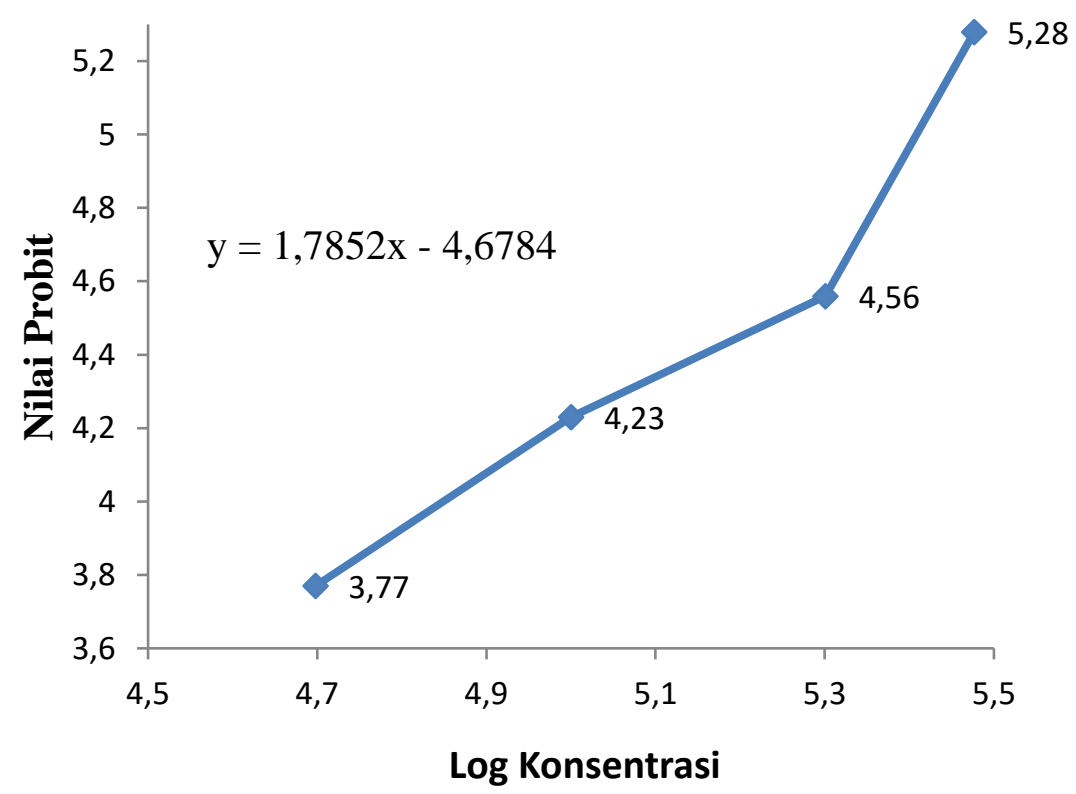

Gambar 1 Grafik N ilai Probit M ortalitas Kecoa A merika Terhadap Ekstrak Kulit Durian. 
Berdasarkan grafik nilai probit mortalitas ekstrak kulit durian terhadap kecoa amerika, dapat dilihat dengan jelas terjadi peningkatan kematian kecoa amerika dari konsentrasi ekstrak yang terkecil hingga konsentrasi ekstrak yang terbesar. Selain itu didapatkan nilai $L C_{50}$ dari grafik mortalitas kecoa amerika tersebut sebesar $2,63 \times 10^{5}$ ppm. LC 50 adalah suatu perhitungan untuk menentukan keaktifan dari suatu ekstrak dan menunjukan konsentrasi ekstrak yang dapat mematikan kecoa yang di uji sebanyak 50\% pada waktu tertentu (Wahyuni \& Asyari, 2016).

\section{PEMBAHASAN}

Untuk mengetahui kandungan pada ekstrak kulit durian digunakan uji fitokimia senyawa metabolik sekunder. Hasil dari uji fitokimia menunjukkan bahwa pada kulit durian positif mengandung senyawa aktif flavonoid, saponin, tanin dan alkaloid. Positifnya uji senyawa saponin ditandai dengan terbentuknya busa yang bertahan selama 5 menit, uji senyawa flavonoid dikatakan positif karena terjadinya perubahan warna coklat menjadi warna jingga setelah ditetesi dengan $\mathrm{HCl}$ pekat dan magnesium, uji senyawa alkaloid ditandai dengan terbentuknya endapan putih setelah ekstrak kulit durian ditetesi dengan $\mathrm{HCl}$ pekat, akuades dan perekasi mayer, dan uji senyawa tanin ditandai dengan terbentuknya larutan hitam kehijauan setelah ditetesi dengan $\mathrm{FeCl}_{3}$ (Arlofa, 2015).

Hasil pengamatan proses kematian kecoa amerika diberikan ekstrak kulit durian terlihat kecoa tampak gelisah melakukan gerakan turun naik, tubuh melemah dan tidak dapat menggerakan badan sehingga mati. Kematian kecoa amerika terendah pada konsentrasi $5 \%$ yaitu mencapai persentase $11,11 \%$ dan kematian tertinggi pada konsentrasi $30 \%$ yaitu mencapai persentase $61,11 \%$, sedangkan $L C_{50}$ yang didapatkan selama 3 jam pengujian yaitu $2,63 \times 10^{5} \mathrm{ppm}$.

Terjadi perbedaan kematian kecoa amerika dipengaruhi oleh konsentrasi ekstrak kulit durian. Semakin tinggi konsentrasi ekstrak yang diberikan maka semakin tinggi pula angka kematian dari kecoa amerika. Banyaknya jumlah kematian kecoa amerika tergantung pada jumlah senyawa yang terkandung pada tiap-tiap konsentrasi, dimana semakin tinggi konsentrasi maka kandungan senyawa insektisida yang bersifat sebagai racun bagi serangga akan lebih banyak (Kardinan, 2007). Pada penelitian ini kematian kecoa amerika ditandai dengan tidak bergeraknya saat disentuh dengan pingset. Senyawa yang terkandung di dalam ekstrak kulit durian yang dapat membunuh kecoa amerika yaitu flavonoid, saponin, tanin dan alkaloid.

Dari hasil pengamatan yang dilakukan pada kecoa dimana tubuh kecoa diam dan mati hal ini disebabkan oleh adanya senyawa flavonoid. Senyawa flavonoid yang merupakan racun pernafasan yang dihirup oleh kecoa mengakibatkan langsung ke pernapasan kecoa sehingga tubuh melemah dan menyebabkan kelemahan syaraf. Menurut (Yunikawati dkk, 2013) flavonid merupakan inhibitor pernapasan dengan mekanisme yang dapat melemahkan saraf. Flavonoid salah satu golongan fenol alam terbesar yang mempunyai kecenderungan untuk mengikat protein sehingga mengganggu proses matabolisme yang menyebabkan kematian pada serangga. 
Saponin yang terhirup oleh kecoa mengakibatkan tubuh kecoa lemah dan mati, karena adanya senyawa saponin yang mengakibatkan penurunan asupan nutrisi. (Sunarjono, 2005) menjelaskan saponin merupakan senyawa aktif yang dapat menimbulkan busa, saponin dapat menyebabkan hemolisis sel darah merah, mempunyai rasa pahit dan menurunkan tegangan permukaan sehingga merusak membran sel, dapat menggangu metabolisme serangga dan menurunkan nafsu makan kemudian serangga mati karena kelaparan.

Tanin merupakan salah satu jenis senyawa yang termasuk ke dalam golongan polifenol. Senyawa astringent tanin dapat menginduksi pembentukan kompleks ikatan tanin terhadap ion logam yang dapat menambah daya toksisitas tanin. Mekanisme kerja tanin diduga dapat mengkerutkan dinding sel atau membran sel sehingga mengganggu permeabilitas sel yang mengakibatkan sel tidak dapat melakukan aktivitas hidup sehingga pertumbuhannya terhambat dan mengalami kematian (Arlofa, 2015).

(Cania \& Setyaningrum, 2013) menjelaskan alkaloid dapat berperan sebagai racun saraf dengan cara menghambat kerja dari enzim saraf, sehingga akan terjadi kegagalan fungsi dari sistem saraf yang akhirnya akan menyebabkan kekakuan pada sistem penghantar impuls menuju sistem otot. Kondisi ini mengakibatkan otot kejang, knockdown dan menyebabkan kematian pada serangga.

Pada kontrol positif digunakan baygon dengan kandungan sipermetrin, yang ditandai dengan lumpuhnya pergerakan dari serangga. (Raini, 2009) menjelaskan sipermetrin ini adalah salah satu golongan insektisida yang digunakan sebagai membunuh serangga. Sedangkan pada kontrol negatif akuades, menujukan tidak ada kecoa amerika yang mengalami kematian. Hal ini disebabkan karena kontrol negatif tidak mengandung senyawa toksik yang dapat mematikan kecoa amerika, sehingga kecoa amerika dapat berkembang dengan baik

\section{KESIM PULAN}

H asil identifikasi senyawa Fitokimia, kulit durian mengandung senyawa flavonoid, saponin, alkaloid dan tanin. Persentase mortalitas kecoa amerika pada konsentrasi 5\%, 10\%, 20\%, dan 30\% berturut-turut yaitu $11,11 \%$, $22,22 \%, 33.33 \%$, dan $61,11 \%$ dengan nilai $L_{50} 2,63 \times 10^{5} \mathrm{ppm}$. 


\section{UCAPAN TERIMA KASIH}

Penulis mengucapkan terima kasih kepada Laboratorium Mikrobiologi \& Parasitologi Yayasan AAK Fajar Universitas A bdurrab Pekanbaru dan Laboratorium Kimia Organik Fakultas M atematika dan IImu Pengetahuan Alam U niversitas Riau Pekanbaru yang telah bersedia sebagai tempat pelaksanaan penelitian dan kepada semua pihak yang telah membantu saran dan petunjuk sehingga penelitian telah berhasil dilaksanakan.

\section{DAFTAR PUSTAKA}

Amalia, H., \& Harahap, I. S. (2010). Preferensi Kecoa Amerika (Periplaneta americana) terhadap Berbagai Kombinasi Umpan. Jurnal Entomologi Indonesia. Volume72): Halaman 67 - 77.

Arlofa, N . (2015). Uji Kandungan Senyawa Fitokimia Kulit Durian sebagai Bahan Aktif Pembuatan Sabun. Jurnal Chemtech. Volume 1 (1): Halaman 18-22.

Astuti, R., \& Soekardi, H. (2014). Pengaruh Ekstrak Daun Sirsak (Annona muricata L) Terhadap M ortalitas Kecoa Amerika (Periplaneta americana) Dewasa. Jurnal Pengembangan Teknologi Pertanian. V olume 7 (2): H alaman $292-298$.

Cania, E., \& Setyanimgrum, E. (2013). Uji Efektivitas Larvasida Ekstrak Daun Legundi (VitexTrifolia) Terhadap Larva A edes A egypti.Journal Medical of Lampung University.V olume2 (4): H alaman 52 - 180.

Kardina, A. (2007). Daya Tolak Ekstrak Tanaman Rosemary (Rosmarinus Officinalisl) Terhadap Lalat Rumah (M usca domestica). Jurnal Bul Littro. Volume 18 (2): Halaman 170 - 176.

Mardiyah, S., \& Royaldi, M. I. (2005). Efektifitas Pengusir Nyamuk Elektrik dari Ekstrak Kulit Durian (Durio zibethinus Murr). Journal Of M uhammadiyah M edical Laboratory Technologist. V olume 2 (2): H alaman $70-76$.

Ningsih, G., U tami, S. R., \& N ugrahani, R. A. (2015). Pengaruh Lamanya W aktu Ekstraksi Remaserasi Kulit Buah Durian Terhadap Rendaman Saponin Dan A plikasinya Sebagai Zat Anti Jamur. Jurnal Konversi. Volume4 (1): Halaman 8-16.

Prabowo, A. (2012). Analisis Kulit Buah Durian. Bandung: Pustaka Grafik.

Raini, M. 2009. Toksikologi Insektisida Rumah Tangga dan Pencegahan Keracunan. Media Peneliti dan Media Pengembangan Kesehatan. V olume 19 (1) : H alaman 27 - 33.

Sucipto, C. D. (2011). Vektor Penyakit Tropis. Yogyakarta: Gosyen Publishing.

Sunarjono, H. (2005). Sirsak Srikaya Budi Daya Untuk Menghasilkan Buah Prima (Cetakan ke 2). Jakarta: Penebar Swadaya.

Triwibowo, C., \& Pusphandani, M. E. (2013). Kesehatan Lingkungan dan K3. Yogyakarta: N uha M edika. Wahyuni, D., \& Asyari, L. A. (2016). Formulasi LC50 Bioinsektisida Baru Ekstrak Biji Pepaya (Carica papaya L.), Biji Srikaya (Anona squamosa L.) Dan Biji Alpukat (Persea americana MILL.) Terhadap M ortalitas Larva Nyamuk A edes aegypti L. Jurnal Sains Dan Teknologi. V olume1 (3). H alaman: 118-123. 
W ahyuni, D., M akomulamin, \& Sari, N. P. (2017). Buku Ajar Entamologi Dan Pengendalian Vektor (Cetakan Ke 1). Yogyakarta: D eepublish.

Yunikawati, M. P. A., Besung, I. N. K., \& M ahatmi, H . (2013).Efektifitas Perasan Daun Srikaya Terhadap Daya H ambat Pertumbuhan Escherichia coli. Jurnal Indonesia M edicus Veterinus. V olume 2(2): H alaman 170179.

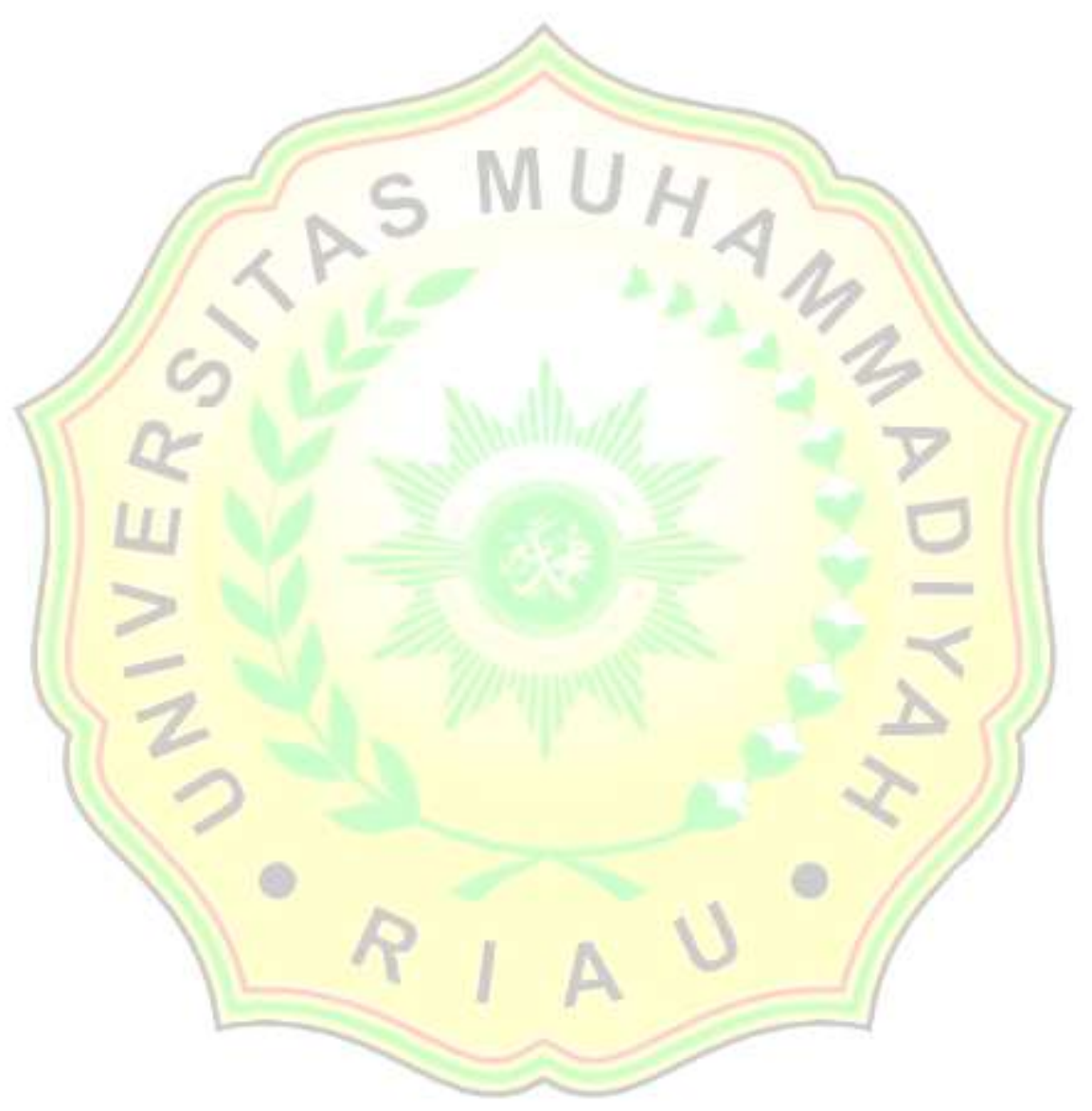

